\title{
Effect of polyphenol extract from Zanthoxylum bungeanum Maxim. on endocrine hormones and monoamine oxidase activity in a mouse model of climacteric depression
}

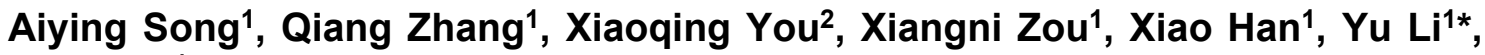 \\ Yin Tang ${ }^{1}$ \\ ${ }^{1}$ The First Clinical Medical College of Heilongjiang University of Chinese Medicine, ${ }^{2}$ The Second Clinical Medical College of \\ Heilongjiang University of Chinese Medicine, Haerbin, PR China
}

*For correspondence: Email: aneesa@qau.edu.pk; Tel: +92-51-90643223

Sent for review: 16 March 2020

Revised accepted: 20 May 2020

\begin{abstract}
Purpose: To investigate the effects of polyphenol extract from Zanthoxylum bungeanum Maxim. $(Z P P C)$ on endocrine hormones, monoamine oxidase activity and behavior in a mouse model of climacteric depression.

Methods: Institute of Cancer Research (ICR) female albino mice $(n=50)$ weighing $24-26 \mathrm{~g}$ (mean wt $=25.0 \pm 1.0 \mathrm{~g}$ ) were randomly assigned to five groups of ten rats each: normal control group, negative control, and ZPPC (50 mg/kg), ZPPC (100 mg/kg) and ZPPC (200 mg/kg) groups. Depression was induced in the mice via oral administration of moclobemide at a dose of $20 \mathrm{mg} / \mathrm{kg}$, and intraperitoneal injection of imipramine $(20 \mathrm{mg} / \mathrm{kg}) 1 \mathrm{~h}$ and $30 \mathrm{~min}$, before treatment. Tail suspension, forced swimming and voluntary activity tests were performed on the mice. The activity of monoamine oxidase (MAO) in mouse brain and the levels of endocrine hormones were also determined.

Results: Treatment of depressed mice with ZPPC significantly and dose-dependently increased their tail suspension and immobility time $(p<0.05)$. The activity of monoamine oxidase in the brains of mice in the negative control group was significantly higher than that of normal control mice, but was significantly and dose-dependently reduced by ZPPC treatment $(p<0.05)$. Similarly, treatment of depressed mice with ZPPC significantly and dose-dependently reduced their serum adrenocorticotropin and corticosterone levels $(p<0.05)$.

Conclusion: The results of this study indicate that ZPPC exerts antidepressant effect via suppression of brain MAO activity.

Keywords: Climacteric depression, Endocrine hormones, Menopause, Monoamine oxidase, Polyphenols

This is an Open Access article that uses a fund-ing model which does not charge readers or their institutions for access and distributed under the terms of the Creative Commons Attribution License (http://creativecommons.org/licenses/by/4.0) and the Budapest Open Access Initiative (http://www.budapestopenaccessinitiative.org/read), which permit unrestricted use, distribution, and reproduction in any medium, provided the original work is properly credited.

Tropical Journal of Pharmaceutical Research is indexed by Science Citation Index (SciSearch), Scopus, International Pharmaceutical Abstract, Chemical Abstracts, Embase, Index Copernicus, EBSCO, African Index Medicus, JournalSeek, Journal Citation Reports/Science Edition, Directory of Open Access Journals (DOAJ), African Journal Online, Bioline International, Open-J-Gate and Pharmacy Abstracts
\end{abstract}

\section{INTRODUCTION}

According to World Health Organization (WHO), depression, which has a lifetime prevalence of more than $15 \%$, may become the second leading cause of death worldwide after cancer [1]. Climacteric depression is a common mental disorder in women. In addition to emotional 
disorders, patients suffering from depression present obvious physical symptoms such as loss of appetite, upper abdominal discomfort, dry mouth, constipation, diarrhea, and in severe cases, suicidal thoughts, and impaired social function [2]. The physiological changes which precede mental symptoms aggravate depression, especially in women [3]. The results of clinical studies show that the incidence of climacteric depression accounts for about $6 \%$ of climacteric population and $78 \%$ of climacteric syndrome, and about $80 \%$ of menopausal women usually experience mood disorders [4]. The incidence of suicide is higher in menopausal women than in men of same age [4].

The involvement of monoamine neurotransmitters in the pathogenesis of depression has been reported [5]. Antidepressants currently used for the management of depression are ineffective and produce adverse reactions, and this has necessitated the search for novel compounds that are safe and effective against depression.

Studies have shown that some preparations used in Traditional Chinese Medicine (TCM) have shown potential as effective antidepressants [6]. They have been reported to protect neurons via regulation of the function of HPA axis and neurotransmitters in the brain [6]. Zanthoxylum bungeanum, the mature dry pericarp of Rutaceae, is used to relieve pain, repel insects, create conditions of dryness and dampness, kill insects and relieve itching. It has been reported that acute administration of ZPPC produces significant antidepressant effect in mouse model of behavioral despair [7].

The present study investigated the effects of ZPPC on endocrine hormones, monoamine oxidase activity and behavior in mouse model of climacteric depression.

\section{EXPERIMENTAL}

\section{Drugs and reagents}

Moclobemide and imipramine were obtained from Shanghai Jinma Experimental Equipment Co. Ltd. Cloclobin, dihydrobromocanine ureamine and 4-hydroquinoline were products of Sigma-Aldrich (USA). DigBehv Animal Behavior Analysis System was purchased from Jiangsu Cyon Biotechnology Co. Ltd. Fluorescence spectrophotometer (R-5000) was purchased from Shimadu Company (Japan). Refrigerated centrifuge (TGL-16GA) was a product of Hunan Xiangxin Instrument Co. Ltd, while FSH-II highspeed electric homogenizer was obtained from
Jintan Jiamei Instrument Co. Ltd. Automatic enzyme marker 550 was purchased from BioRad (USA), while BS110S analytical balance was a product of Shanghai Aozhi Electronic Technology Co. Ltd.

This research was approved by the Animal Ethical Committee of The First Clinical Medical College of Heilongjiang University of Chinese Medicine, Haerbin, China (the approval no. 201921363), carried out according to Principles of Laboratory Animal Care [8].

\section{Mice}

Fifty Institute of Cancer Research (ICR) female albino mice $(n=50)$ weighing $24-26 \mathrm{~g}$ (mean weight $=25.0 \pm 1.0 \mathrm{~g}$ ) were purchased from Guangdong Medical Laboratory Animal Center (No. 2018C028). They were housed in metal cages in a greenhouse under standard conditions and had free access to standard feed and water in an environment with equal light/dark periods at $25{ }^{\circ} \mathrm{C}$ and $60 \%$ humidity. They were acclimatized to the laboratory conditions for three days prior to commencement of the study. The study protocol received approval from the Institutional Animal Ethics Committee of First Clinical Medical College of Heilongjiang University of Chinese Medicine, Haerbin, China and the study procedures were carried out according to the guidelines of the National Institute of Health (NIH) for the use and care of experimental animals. The mice were first subjected to double-strategy ovariectomy before the commencement of study proper.

\section{Animal grouping and treatment}

The mice were randomly assigned to five groups of ten rats each: normal control group, negative control, ZPPC (50 mg/kg), ZPPC (100 mg/kg) and ZPPC (200 mg/kg bwt) groups. Depression was induced in the mice via oral administration of moclobemide at a dose of $20 \mathrm{mg} / \mathrm{kg}$ and intraperitoneal injection of imipramine $(20 \mathrm{mg} / \mathrm{kg}$ bwt) $1 \mathrm{~h}$ and $30 \mathrm{~min}$, respectively, before treatment. Mice in control group were given an equivalent volume of double-distilled water in place of drug.

\section{Tail suspension test}

Exactly $1 \mathrm{~h}$ after commencement of treatment, the mice were fixed on an iron shelf about $2 \mathrm{~cm}$ away from the tail tip with adhesive tape. The head of each mouse was positioned downward from the box (15 cm from the bottom of the box). At the start, the mouse head was moved from side to side until the number of movements 
decreased, and this was taken as intermittent immobility. The behavior of each mouse was noted and recorded within 6 min.

\section{Forced swimming test}

Usually, when a mouse is placed in water, it gasps for air, and after some time, it stops struggling, floats in the water and stays still, or does the necessary little movement to keep its head on the surface of the water. Exactly $24 \mathrm{~h}$ before commencement of the test, the mice were placed in $1500 \mathrm{~mL}$ glass beaker maintained at 25 ${ }^{\circ} \mathrm{C}$. Then, the mice were trained to swim for 15 min. One hour after treatment, the mice were again placed in the beaker and forced to swim for $6 \mathrm{~min}$. The time it took each mouse to rest was observed and recorded within $4 \mathrm{~min}$.

\section{Voluntary activity test}

The mice were placed in a voluntary activity tester $1 \mathrm{~h}$ after drug administration, and the activity of each mouse was recorded using an inbuilt camera. After the mice acclimatized to the environment for $10 \mathrm{~min}$, their activity time were observed, recorded and taken as index of independent activity.

\section{Determination of monoamine oxidase activity}

One hour after drug administration, the mice were decapitated and their brains were quickly isolated on ice, and weighed. Then, $4 \mathrm{~mL}$ of cold phosphate buffer $(0.05 \mathrm{~mol} / \mathrm{L})$ was used to homogenize the brain tissues. Subsequently, 0.4 $\mathrm{mL}$ of $20 \%$ Triton, $0.2 \mathrm{~mL}$ tissue homogenate and $2.5 \mathrm{~mL}$ phosphate buffer were thoroughly mixed. The solution was pre-incubated for $10 \mathrm{~min}$ at $38{ }^{\circ} \mathrm{C}$, and $30 \mathrm{~mL}$ of $12.19 \mathrm{mmol} / \mathrm{L}$ substrate was thereafter added and pre-incubated for another $30 \mathrm{~min}$ at $37^{\circ} \mathrm{C}$.

About $0.2 \mathrm{~mL}$ of $5 \mathrm{~mol} / \mathrm{L}$ perchloric acid was added, followed by cooling and centrifugation for $10 \mathrm{~min}$ at $1500 \mathrm{rpm}$ to obtain supernatant, 0.5 $\mathrm{mL}$ aliquot of which was mixed with $2.5 \mathrm{~mL}$ of 1.0 $\mathrm{mol} / \mathrm{L}$ sodium hydroxide $(\mathrm{NaOH})$ solution, and read using fluorescence spectrophotometer. The protein content was measured using Bradford method.

\section{Determination of levels of adrenocortico- tropin and corticosterone in the mice}

The levels of adrenocorticotropin and corticosterone in mice were determined using radioimmunoassay kit (BoYu biotech, Shanghai, China).

\section{Statistical analysis}

Data are expressed as mean \pm SD. Statistical analysis was performed using SPSS (15.0). Groups were compared using Rank sum test. Values of $p<0.05$ were taken as indicative of significance.

\section{RESULTS}

\section{Effect of ZPPC treatment on tail suspension time}

Treatment of depressed mice with ZPPC significantly and dose-dependently increased their tail suspension time $(p<0.05$; Figure 1).

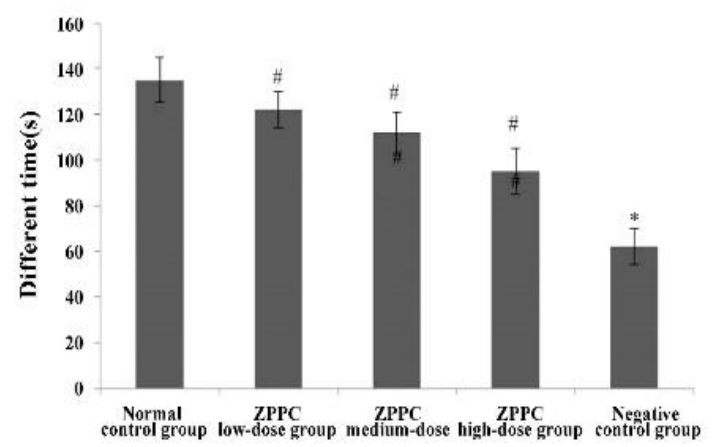

Figure 1: Effect of ZPPC on tail suspension time in depressed mice. ${ }^{*} p<0.05$, vs normal control; ${ }^{*} p<$ 0.05 , vs negative control

\section{Effect of ZPPC on immobility time in depressed mice}

The immobility time of mice in negative control group was significantly reduced relative to that of normal control group, but was significantly and dose-dependently increased after treatment with ZPPC $(p<0.05)$. These results are shown in Figure 2.

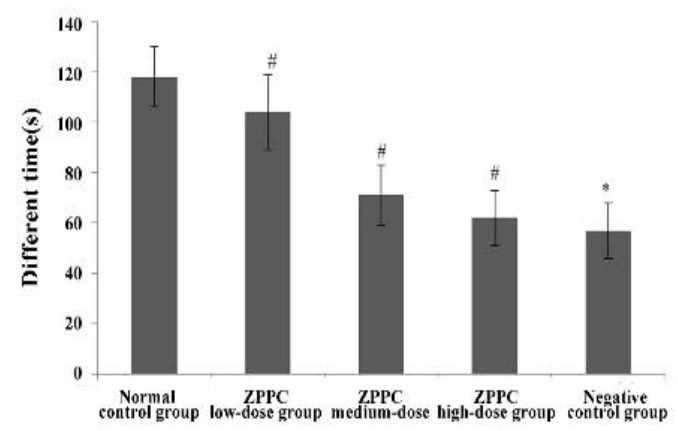

Figure 2: Effect of ZPPC on immobility time of depressed mice. ${ }^{*} P<0.05$, vs normal control; ${ }^{\#} p<$ 0.05 , vs negative control 
Influence of ZPPC on voluntary activities in depressed mice

As shown in Figure 3, there were no significant differences in voluntary activities among the mouse groups $(p>0.05)$.

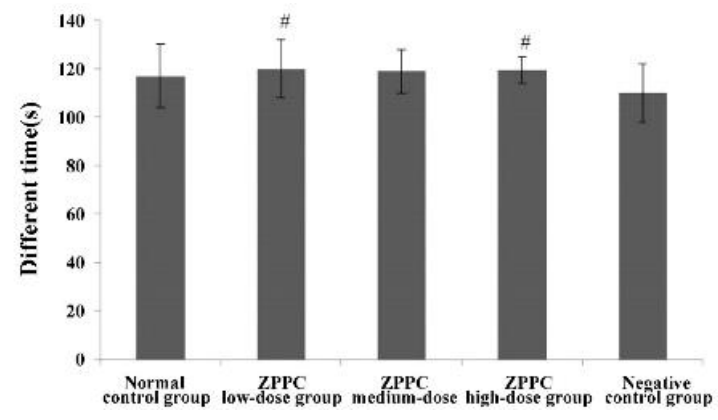

Figure 3: Voluntary activity in depressed mice after treatment with ZPPC. ${ }^{*} P<0.05$, vs normal control; ${ }^{*} p$ $<0.05$, vs negative control

Monoamine oxidase activities in brains of depressed mice

The activities of monoamine oxidase in the brains of mice in negative control group were significantly higher than those of normal control group mice, but were significantly and dosedependently reduced by ZPPC treatment $(p<$ 0.05; Figure 4).

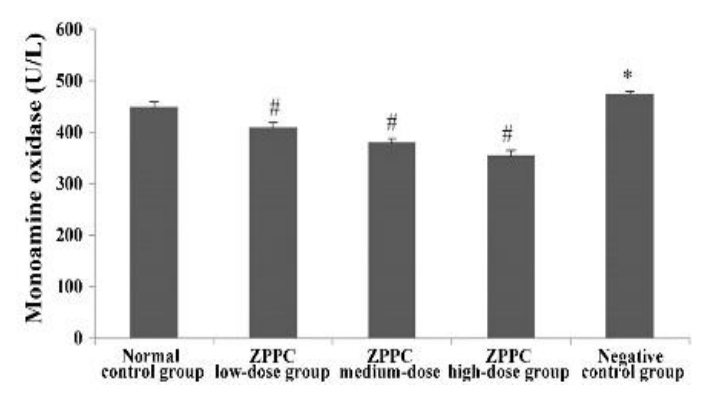

Figure 4: Effect of ZPPC on monoamine oxidase activities in brain tissues of depressed mice. ${ }^{*} P<0.05$, vs normal control; ${ }^{\#} p<0.05$, vs negative control

\section{Levels of endocrine hormones in depressed mice}

Treatment of depressed mice with ZPPC significantly and dose-dependently reduced their adrenocorticotropin and corticosterone levels ( $p$ $<0.05$; Table 1).

\section{DISCUSSION}

Depression, a mental health disorder characterized by persistently depressed mood or loss of interest in activities, causes significant impairment to daily life. It is common in perimenopausal women. Studies have shown that impaired ovarian function after menopause contributes significantly to the onset of climacteric depression [9].

Table 1: Effect of ZPPC on levels of endocrine hormones in depressed mice

\begin{tabular}{lcc}
\hline Group & $\begin{array}{c}\text { Adrenocortic } \\
\text { otropin } \\
\text { (mg/kg } \\
\text { tissue) }\end{array}$ & $\begin{array}{c}\text { Corticosterone } \\
\text { (mg/kg tissue) }\end{array}$ \\
\hline $\begin{array}{l}\text { Normal } \\
\text { control }\end{array}$ & $18.61 \pm 1.51$ & $10.21 \pm 0.71$ \\
$\begin{array}{l}\text { Negative } \\
\text { control }\end{array}$ & $98.41 \pm 6.41^{*}$ & $47.21 \pm 2.31^{*}$ \\
$\begin{array}{l}\mathrm{ZPPC}(50 \\
\mathrm{mg} / \mathrm{kg})\end{array}$ & $85.91 \pm 4.01^{\#}$ & $41.41 \pm 0.81^{\#}$ \\
$\begin{array}{l}\mathrm{ZPPC}(100 \\
\mathrm{mg} / \mathrm{kg})\end{array}$ & $74.61 \pm 3.81^{\#}$ & $34.41 \pm 1.81^{\#}$ \\
$\begin{array}{l}\mathrm{ZPPC}(200 \\
\mathrm{mg} / \mathrm{kg})\end{array}$ & $46.01 \pm 4.21^{\#}$ & $17.81 \pm 1.11^{\#}$ \\
\hline
\end{tabular}

${ }^{*} p<0.05$, vs normal control; ${ }^{*} p<0.05$, vs negative control

Forced swimming test (FST), a simple, easy, reliable and effective animal model of depression, is used to screen drugs with potential antidepressant effects [10]. Other behavioral despair models have been established, which take clues from FST, the most prominent of which is the mouse tail suspension test (MTST) [11]. In this test, there is usually significant reduction in the number of survival activities due to disappointment and the mice appear to be in an intermittent static state, manifested as desperate state. Immobility is a kind of adaptive behavior which occurs after depressed animals try to escape, but fail, and it is considered to be an indicator of depression [12]. The results of this study showed that the immobility time of mice in negative control group was significantly longer than that of normal control group, but was significantly and dosedependently shortened by ZPPC treatment. These results suggest that pretreatment of mice with ZPPC may confer some antidepressant effect on them.

In order to distinguish antidepressants from nonantidepressants using a mouse model, it is important to observe spontaneous activity of the mice. In this study, there were no significant differences in total exercise distance among the treatment groups, an indication that ZPPC may have no effect on spontaneous behavior of the mice. In an earlier study, it was hypothesized that estrogen withdrawal for the first time could contribute to the onset of climacteric depression [13]. The gradual decline in ovarian function in climacteric women leads to significant reduction 
in estrogen secretion, and the resultant low level of estrogen contributes significantly to the onset of depression or aggravates the condition.

Clinical studies have shown that estrogen and progesterone affect monoamine oxidase denaturation and serotonin metabolism [14]. Both hormones regulate the expression of serotonin receptor. The pathogenesis of climacteric depression may be related to the activity of postsynaptic serotonin receptor [15]. Estrogen promotes the growth and development of neurons and synapses at the genetic level [16]. In this study, treatment of depressed mice with ZPPC significantly and dose-dependently reduced their adrenocorticotropin and corticosterone levels. It is suggested that the antidepressant effect of ZPPC pretreatment may be related to suppression of brain MAO activity.

\section{CONCLUSION}

The results of this study indicate that ZPPC exerts antidepressant effect via suppression of brain MAO activity, and therefore could find clinical application in the treatment of depression.

\section{DECLARATIONS}

\section{Acknowledgement}

\section{Conflict of interest}

No conflict of interest is associated with this work.

\section{Contribution of authors}

We declare that this work was done by the author(s) named in this article and all liabilities pertaining to claims relating to the content of this article will be borne by the authors, all authors read and approved the manuscript for publication. $\mathrm{Yu} \mathrm{Li}$ conceived and designed the study, Aiying Song, Qiang Zhang, Xiaoqing You, Xiangni Zou, Xiao Han, Yu Li, Yin Tang collected and analysed the data, Aiying Song wrote the manuscript.

\section{Open Access}

This is an Open Access article that uses a funding model which does not charge readers or their institutions for access and distributed under the terms of the Creative Commons Attribution License (http://creativecommons.org/licenses/by/ 4.0) and the Budapest Open Access Initiative (http://www.budapestopenaccessinitiative.org/rea d), which permit unrestricted use, distribution, and reproduction in any medium, provided the original work is properly credited.

\section{REFERENCES}

1. Macíascortés E, Llanesgonzález L, Aguilarfaisal L, Asbun-Bojalil J. Response to Individualized Homeopathic Treatment for Depression in Climacteric Women with History of Domestic Violence, Marital Dissatisfaction or Sexual Abuse: Results from the HOMDEP-MENOP Study. Homeopathy 2018; 107: 38.

2. Quiroga A, Larroy $C$, González-Castro $P$. Climacteric symptoms and their relation to feminine self-concept. Climacteric 2017; 20: 274-279.

3. Stadler A, Weidlinger $S$, Stute $P$. Impact of endogenous and exogenous progesterone exposure on stress biomarkers: a systematic review. Climacteric 2019; 22(5): 435-441.

4. Macías-Cortés ED, Llanes-González L, Aguilar-Faisal L, Asbun-Bojalil J. Is metabolic dysregulation associated with antidepressant response in depressed women in climacteric treated with individualized homeopathic medicines or fluoxetine? The HOMDEP-MENOP Study. Homeopathy 2017; 106(1): 3-10.

5. Endendijk JJ, Spencer H, van Baar AL, Bos PA. Mothers' neural responses to infant faces are associated with activation of the maternal care system and observed intrusiveness with their own child. Cogn Affect Behav Neurosci 2018; 18(4): 609-621.

6. Redpath $N$, Rackers HS, Kimmel MC. The Relationship Between Perinatal Mental Health and Stress: a Review of the Microbiome. Curr Psychiatry Rep 2019; 21(3): 18.

7. Chen X, Wei Z, Zhu L, Yuan X, Wei D, Peng W, Wu C. Efficient Approach for the Extraction and Identification of Red Pigment from Zanthoxylum bungeanum Maxim and Its Antioxidant Activity. Mol 2018; 23(5): 1109.

8. World Health Organization. Principles of laboratory animal care. WHO Chron 1985; 39: 51-56.

9. Gao L, Zhang L, Qi H, Petridis L. Middle-aged Female Depression in Perimenopausal Period and Square Dance Intervention. Psychiatr Danub 2016; 28(4): 372378.

10. Park SH, Jang S, Lee SW, Park SD, Sung YY, Kim HK. Akebia quinata Decaisne aqueous extract acts as a novel anti fatigue agent in mice exposed to chronic restraint stress. J Ethnopharmacol 2018; 222: 270-279.

11. Steru L. The tail suspension test: a new method for screening antidepressants in mice. Psychopharmacol (Berl) 2017; 85(2): 367-378.

12. Suvrathan A, Raymond JL. Depressed by LearningHeterogeneity of the Plasticity Rules at Parallel Fiber Synapses onto Purkinje Cells. Cerebellum 2018; 17(6): 747-755.

13. Bixo M, Johansson M, Timby E, Michalski L, Bäckström $T$. Effects of GABA active steroids in the female brain with focus on the premenstrual dysphoric disorder. $J$ Neuroendocrinol 2018; 30(2): 12553.

Trop J Pharm Res, June 2020; 19(6): 1267 
14. Bergvall O. Equivariant cohomology of the moduli space of genus three curves with symplectic level two structure via point counts. Eur J Math 2019; 55(3): 1-59.

15. Le Cornet C, Johnson TS, Lu DL, Kaaks R, Fortner RT. Association between lifestyle, dietary, reproductive, and anthropometric factors and circulating 27hydroxycholesterol in EPIC-Heidelberg. Cancer Causes Control 2020; 31(2): 181-192.
16. Theofilopoulos S, Wa ADO, Yang S, Yutuc E, Saeed A, Abdel-Khalik J, Ullgren A, Cedazo-Minguez A, Björkhem I, Wang $Y$, et al. 24(S), 25-Epoxycholesterol and cholesterol 24S-hydroxylase (CYP46A1) overexpression promote midbrain dopaminergic neurogenesis in vivo. $\mathrm{J}$ Biol Chem 2019; 294(11): 4169-4176. 